\title{
SHEIKH YŪSUF AL-MAQASSARY AND HIS REFORM IDEAS IN THE SPREAD OF ISLAM IN GOWA-MAKASSAR IN THE SEVENTEENTH CENTURY
}

\author{
ABD. RASYID MASRI \\ Fakultas Dakwah dan Komunikasi \\ Universitas Islam Negeri (UIN) Alauddin Makassar \\ Email : marcellaafrianny@gmail.com
}

\begin{abstract}
:
This paper relates to the brief history of Sheikh Yōsuf al-Makassary as well as his brief role in the Spread of Islam in Gowa-Makassar as his birth land. Sheikh Yōsuf was born in $1626 \mathrm{M}$ and grew up among noble families of Gowa-Tallo Kingdoms and then travelled to seek and deepen his Islamic knowledge from Aceh, India to the middle East (1645-1668) or for around 23 years and then he became a great șifi and left many of his treatises for Islamic community, especially for his followers, which are most of them still preserved at Universiteit Bibliotheq Leiden and the national museum of Jakarta at the present day. The main concept of Islamic mysticism of Sheikh Yvisuf as one of his reform in the spread of Islam in Gowa-Makassar is the purification of belief ('aqidah) in the Oneness of Allāh or in the Unity of God (tawhìd). This is his attempt to explain God's transcendence (Ilāh) on His creatures. In a quoted al-Ikhlash verse (QS. 112:1-4) and al-Shura'verse of al-Qur'an that there is nothing comparable to Him (QS. 42: 11), Sheikh Yṽsuf emphasized that the Oneness of Allāh is infinite and absolute. Tawhìd is the essential component in Islam.
\end{abstract}

Keywords : Sheikh Yv̄suf, Reform Ideas, Islamic mysticism, and the Spread of Islam in Gowa-Makassar

\section{INTRODUCTION}

Sheikh Yv̄suf (1036-1110H/1626-1699) is a șvfī Islamic scholar and a National hero of two countries, Indonesia and South Africa. He was born by the marriage of 'Abd Allāh Tuanta Manjalāwī (a Sheikh who was considered from 'Alawīl 'Alawiyyīn descendant (Sayyidinā Ali $k w$. and Fatimah bt. Muhammad pbuh.), Haḑramawt, Yemen with Aminah I Tubiani Daeng Kunjung. He grew up amongst the noble families of Gowa-Tallo Kingdoms and then he wandered to seek and to deep his Islamic knowledge from Aceh, India until the Middle East (1645-1668). When he returned to his country, he stayed in Banten for a long time becoming a war leader as a defender of human rights towards the Dutch East. Indies Company (VOC), then he was exiled to Ceylon (Srilanka) in 1683/16841693 and to the last place of exile for the rest of his life in Cape Town (16941699) in the age of 68 to 73 years by the Dutch Colonizers. ${ }^{1}$

\footnotetext{
${ }^{1}$ See and compare with Muzdalifah Sahib, Syeikh Yusuf al-Maqassary dan Pembaruannya dalam Súfísme. (Makassar, Yayasan al-Mahasin, 2016), Sahib Sultan, Allah dan Jalan Mendekatkan Diri KepadaNya dalam Konsepsi Sheikh Yúsuf. (Makassar:Yapma, 2008); Azyumardi Azra, Jaringan Ulama Timur
} 
Therefore, he spent much time abroad rather than in his country, it is estimated for some 38 years of his life. He taught at al-Haram Mosque between the ages of 36 till 42 years. He is a true scientist model with the greatest motivation, even though at the time there was no government scholarship, foundation grant and super-fast ship. He taught Islamic mysticism for some 37 years of his life, starting in Mecca in 1662, Banten and Makassar, Ceylon, Sri Lanka and then in the Cape, South Africa. He became a mufti in Banten, and when Sultan Ageng Tirtayasa was captured by the Dutch; then the work of Sheikh Yv̄suf changed to be the lead of troops in a brave to fight against the Dutch East Indian Company in the jungle of West Java lasting for a period nearly 2 years. After he was caught and charged with treason, as it was common practiced by the Dutch towards Indonesian warriors, Sheikh Yṽsuf was exiled to Batavia, then to Ceylon and South Africa. ${ }^{2}$

When Sheikh Yv̄suf taught at the al-Haram Mosque, his students consisted of many different nations, and when he was exiled to Ceylon, it was his students from Ceylon and India who come to accompany him. Sheikh Yv̄suf was not only an important scholar for his village, his region or this archipelago or for Indonesia today, he had even crossed the boundary continent and achieved the position as the world figure. Now, he had become a National Hero of two countries, namely Indonesia and South Africa.

Sheikh Yv̄suf was an idol and a model for young generation who longed for/craved and dreamed of such an exemplary figure not only in Indonesia, but also in South Africa.

In terms of Sheikh Y v̄suf and the international network of 'ulamā from Indonesia to the Middle East, he is one of as, of course, who is regarded as a neoast or a reformer in the Islamic mystic world. ${ }^{3}$

During his period on the seventeenth century, he began to make reforms in the field of Mystic teaching. His religious and mystic ideas are mostly in Arabic which still preserved in the Leiden library (UB) and in the National Museum of Jakarta.

The next issues to be discussed are how the role and reform ideas of Sheikh Yūsuf al-Maqassary in the spread of Islam in Gowa-Makassar, South Sulawesi, which of course begins with a discussion of his works and his reforms ideas in the mystical world of Islam.

\section{LITERATURE AND THEORY}

\section{Sheikh Yv̄suf 's Works Written in Banten and Ceylon}

Sheikh Yv̄suf was a $\bar{a}$ Islamic scholar who wandered for a long time in search of Islamic knowledge and in depth his mysticism, especially in the Arabic

Tengah dan Kepulauan Nusantara Abad XVII \& XVIII. Akar Pembaruan Islam di Indonesia. (Edisi Refisi, Jakarta: Kencana, 2007); dan Nabilah Lubis, Syekh Yusuf al-Taj al-Makasari. Menyingkap Intisari Segala Rahasia. (Bekerja sama dengan Fakultas Sastra Universitas Indonesia \& Ecole Francaise d'Extrême-Orient, Bandung: Mizan, 1996).

${ }^{2}$ Compare with Muzdalifah Sahib, Shaykh Yúsuf al-Maqassarí His life Story as a National Hero from Gowa, South Sulawesi to Cape Town, South Africa and a Reformer in the Islamic Mystic World. (Makassar: Alauddin University Press, 2014). 236.

${ }^{3}$ See and Compare with Azra Azyumardi, Jaringan Ulama...., p. 288 dan Sultan, Sahib, Allah...., p. 
peninsula, leaving many treatises in Arabic language for us as guidance for approaching God.

Muzdalifah Sahib (A PhD researcher of Leiden University and South African University) tried to collect information regarding the works of Sheikh Yusuf either from Leiden or from Indonesia, and she found that there 38 treatises and mostly preserved at Leiden University Library and the National Museum Jakarta.

By this research, it is found some of his treatises or works written in Banten and Ceylon, Srilanka; most of them are in Arabic. Amongst those are in the following:

\section{Sheikh Yōsuf's Works in Arabic}

1) Al-Barkat al-Saylāniyyah or 'the Blessing from Ceylon' (البركات السيلانية) in MSKBG 108, Arabic Microfilm of UB Leiden, F Or A 13b [5] and Jakarta Manuscript A 108.

2) Bidāyat al-Mubtadī or 'Affliction of the Beginner'(بداية المبتدى) in MSKBG 108, Arabic Microfilm of UB Leiden, F Or A 13b [25].

3) Al-Fawāih al-Ȳ̄sufiyyah fì Bayān Tahqūq al-Ṣüfìyya or 'the Benefits Obtained by Explaining the Accomplishments of the Șüfīs, according to Yōsuf'

in MSKBG 108, Arabic Microfilm of UB Leiden, F Or A 13b [6]

4) Hāshiyyah fì Kitāb al-Anbāh fì I'rāb Lā Ilāha Illā Allāh or 'The Gloss to the Book that Explains the Rules of the words Lä Ilāha Illä Allāh.'

(حاشية في كتاب الأنباه في اعراب لا اله الا الله) in Arabic Manuscript of UB Leiden Or 7446 [6]

5) Kaifiyyat al-Nafì Wa al-Ithbāt bi al-Hadīth al-Qudsī or 'the Way of Negation and Affirmation (Dhikr) Via the Hadìth Qudsì.' (كيفية النفي والإثبات بالحديث (لقسسى) in MSKBG 108, Arabic Microfilm of UB Leiden, F Or A 13b [7]

6) Matāilib al-Sālikīn or 'The Endeavours of the Seekers' ( مطالب السالكين) in MSKBG 101, Arabic Microfilm of UB Leiden, F Or A 13d [7] and MSKBG 108, Arabic Microfilm of UB Leiden, F Or A 13b [3]

7) Al-Nafhāt al-Saylāniyyah or 'the Breath from Ceylon' (السيلانية) ) in MSKBG 101, Arabic Microfilm of UB Leiden, F Or A 13d [I]

8) Qurrat al- 'Ayn or 'the Coolness of Eyes' (قرة العين) in Arabic Manuscript of UB Leiden, Or 7025 [4] and MSKBG 101, Arabic Microfilm of UB Leiden, F Or A 13d [13]

9) Sirr al-Asrār or 'the Secret of Secrets' ( ) in Arabic Manuscript of UB Leiden Or 5706 (2): 3-17, and Or 7025 [3]: 67-104; MSKBG 101, Arabic Microfilm of UB Leiden, F Or A 13d [8] and MSKBG 108, Arabic Microfilm of UB Leiden, F Or A 13b [10]

10) Şṽrah 'the Picture (of Tawhīd)' ( ) in MSKBG 108, Arabic Microfilm of UB Leiden, F Or A 13b [24a]

11) Tāj al-Asrār fì Tah̆qūq Mashārib al-'Ārifìn or 'The Crown of Secret in Realizing the Watering Places of the Gnostics' 
(تاج الأسرار في تحقيق مشارب العارفين ) in MSKBG 101, Arabic Microfilm of UB Leiden, F Or A 13b [5] and Arabic Manuscript of UB Leiden Or 7025 [1]

12) Zubdat al-Asrār fī Tahqūq Ba'ḍa Mashārib al-Akhyār or 'the Cream of Secrets in Realizing Some Watering Places of the Chosen Ones' (زبدة الأسرار في تحقيق بعض مشارب الأخيار) in Arabic Manuscript Jakarta A 101 \& Or 7025 [2], Microfilm F Or. A 13d [2] Id; F Or A 13b [33] and F Or A 14b [2].

13) Fath Kaifiyyat al-Dhikr or 'The Explanation concerning the Ways of Doing Dhikr' (فتح كيفية الذكر) in Arabic Manuscript of UB Leiden, Or 7025 [5]

14) Daf'u l-Balā' or 'Repelling Calamity' ( ) in MSKBG 108, Arabic Microfilm of UB Leiden, F Or A 13b [27]

15) Hādhihi Fawā'id 'Azìmah Dhikr Lā Ilāha Illā Allāh or 'This are the Necessary Benefits of Dhikr Lā Ilāha Illā Allāh" (هذه فوائد عظيمة ذكر لا إله إلا ' ) in Arabic manuscript of UB Leiden, F Or 7025 [6]

16) Tahsîl al-'Ināyat wa al-Hidāyat or 'the Result of Help and Guidance' in Arabic Microfilm, F Or A 13b [8]; Jakarta manuscript A 108.

17) Risāla Ghāyat al-Ikhtișār Wanihāyat al-Intizāar or 'The Excellent Treatise in Brevity and the Ultimate Vision.'(رسالة غاية الإختصار ونهاية الإنتظار) in Arabic Microfilm MSKBG 108 F Or A 13b [9]

18) Tuhfat al-Amr fī Faḑilat al-Dhikr or 'The Commanding Gift regarding the Virtues of Dhikr' (تحفة الأمر في فضيلة الأكر) in Arabic Microfilm MSKBG 101 F Or A 13d [6]; and Arabic Manuscript, Or 5706 of UB Leiden

19) Tuhfat al-Abrār li Ahl al-Asrār or 'The gift of the Good Ones to the People of Secrets'تحفة الأبرارلأهل الأسرار) in Arabic Microfilm of UB Leiden, F Or A 13d [9]; Jakarta manuscript A 101, A 113.

20) Talkhīs al-Ma'ārif 'The Synopsis of the Divine Knowledge' ( تلخيس المعا ) in MSKBG 108, Arabic Microfilm of UB Leiden, F Or A 13b [26]

Tuhfat al-Tālib al-Mubtad̄̄ wa Minhat al-Sālik al-Muhtad̄̄ or 'a Gift for a Beginner and Guided Seeker' in MSKBG Arabic Microfilm of UB Leiden, F Or A 14b [1] ( تحفة الطالب المبتدى و منحة السالك المهتد)

21) Safinat al-Najāh or 'The Ark of Safety or theVessel of Salvation' ( سفينة ) in Majmu'ah min Muallafāt li al-Shaykh Yōsuf al-Maqassary.

22) Al-Risālat al-Naqshabandiyya or 'The Work about Tarīqat alNaqshabandiyya' (الرسائة النقشبندية)

23) Asrār al-Șalāh or 'The Secrets of Salah' ( ) in MSKBG 108 Arabic Microfilm of UB Leiden, F Or A 13b [19]

24) Tuhfat al-Mursalat or 'the Gift Given' ( ) in Arabic Manuscript of UB Leiden, Or $7026^{4}$

\section{Other Works of Shaykh Yōsuf}

Besides all of above, there are still other works in Javanese, Buginese and Makassarese (which are as quotation or translation from Arabic by his students).

${ }^{4}$ Muzdalifah Sahib, Shaykh Yúsufal-Maqassari ..., p. 115-121 
The work of Sheikh Yv̄suf that has been translated in Javanese which is called as Barkah Seh Yōsuf Saking Banten (it is not known whether it is translated or written directly in the language, or even who translated it, but it is clear from its name that it is Sheikh Yṽsuf's treatise). ${ }^{5}$ While in Buginese is called Tajeng Patiroannge Lao ri Laleng Malempue by Aḥmad Șāliḥ ${ }^{6}$ and in Makassarese is called Riwayatna Tuanta Salamaka Sehe Yv̄sufu by Nuruddin Dg.Magassing. ${ }^{7}$

\section{THE REFORM IDEAS OF SYEIKH YŪSUF AL-MAQASSARY}

Sheikh Yv̄suf al-Makassary was primarily a șvfi. With respect to his career and teaching, undoubtedly he was one of the most important mujaddids or reformers of mysticism in the history of Islam in the archipelago. His life experiences make it clear that his șvfism did not keep him away from worldly affairs; even he was a $\bar{a}$, Allāh's saint who could fight in the middle of society, reflecting scriptures and praying tahajjud at night, performing act of charity and holding a sharp bamboo cane at noon. Therefore Hamka called him a big șvf $\bar{\imath}$ and mujāhid or a warrior. ${ }^{8}$ Unlike earlier șvfiss who exhibited strong tendencies to shun worldly life, the whole expression of Sheikh Yv̄suf's teaching and practices shows a full range of activism.

Like al-Raniri and Abd. Rauf Al-Sinkili in the Sultanate of Aceh, Sheikh Yv̄suf played an important role in Bantanese politics. Not only that, he also stepped to the forefront of the wars against the Dutch, moreover after the capture of Sultan Ageng Tirtayasa. However, like most scholars in the international networks of scholars in the seventeenth century, Sheikh Yv̄suf did not employ the tariqah organization to mobilize the masses, especially for the purpose of war. ${ }^{9}$

His long sojourn in the Middle East had enabled Sheikh Yv̄suf to write his works in perfect Arabic. Almost all his known works deal with tașawwuf, especially in its relations with kalām science (tawhìd). Like al-Raniri and Abd. Rauf al-Sinkili, Sheikh Yv̄suf in developing his teaching also frequently cites such scholars as Al-Gazali, Imam Shafi' '̄, Junayd al-Baghdadī, Ibn 'Arabī, Z̄̄ al-Nv̄n, Abv̄ Zaid al-Kharrāz, al-Jilli, Ibn 'Ata' Allāh and other authorities.

The following discussion only gives a brief description about his reform ideas in his treatises and especially his reform ideas instilled by Sheikh Yusuf in the spread of Islam in Gowa-Makassar, South Sulawesi.

\section{A. Sheikh Yōsuf's Reform Ideas in Some of His Works}

Some concepts or teaching of Sheikh Yv̄suf considered as his reform in the Islamic mystic world, taken from his works amongst some of his works, based on the result of the research of my friends in the Universiteit bibliotheek Leiden and

\footnotetext{
${ }^{5}$ Noorduyn. "Sejarah Agama Islam di Sulawesi Selatan”, Panggilan Kita di Indonesia Dewasa ini, Susunan W.B. Sijabat (Jakarta: BPK Gunung Agung, 1964): 33

${ }^{6}$ A.A. Cence, "Pemujaan Sheikh Yúsuf di Sulawesi Selatan". Sejarah Lokal di Indonesia. Editor: Taufiq Abdullah. (Yogyakarta: UGM, 1979), p. 179

${ }^{7}$ Nuruddin Dg. Magassing, Riwayatna Tuanta Salamaka Sehe Yúsufu. (Makassar: Volksdrukkerij, 1933)

${ }^{8}$ Hamka. "Perjuangan Syeikh Yusuf Taj al-Khalwati”, Almanak Muhammadiyah. XX, 1959/1960.

h. 27

${ }^{9}$ Azyumardi Azra. Jaringan Ulama ...., p. 289.
} 
Azyumardi Azra (1992 \& 2005). ${ }^{10}$

The main concept of religious and mystic Sheikh Yṽsuf is the purification of belief ( 'aqì $d a$ ) in the Oneness of Allāh or in the Unity of God (tawhìd). This is his attempt to explain God's transcendence (Ilāh) over His creation. Citing alIkhlash verse (QS. 112:1-4) and another verse of Al-Qur'an in al-Shura verse which states that nothing is comparable unto Him (QS. 42: 11), Sheikh Yv̄suf emphasized that the Oneness of Allāh is unlimited and absolute. ${ }^{11}$ Tawhìd is the essential component in Islam; a man who does not have tawhìd is an infidel. More deeply, he illustrates pure tawhi $\bar{l}$ or the immaculate tawhi $\bar{l}$ as a tree with its branch and its leaves; ma 'riffah knowledge is like its branch and its leaves; while prayer is like its fruit. Furthermore he said that if you got the tree, you will get its branches and leaves, and if you got them, even you look for fruit of the tree. If you do not get its branches and leaves, it is impossible to get its fruit. This is a majāzi $\bar{\imath}$ or a metaphor sample that we said, in order that you can understand real nature (actually). A man who does not know ma 'rîfah knowledge is stupid (jāhil) and a man who does not practice 'ibādah or prayer is a sinful man $(f \bar{a} s i q) .{ }^{12}$ Therefore, tawhīd without ma 'riffah is like a tree without branches and leaves, and it is impossible to get its fruit, except if the branches and leaves of the tree grew up again, then its fruit can be hoped. In other words, only a man, who has tawhi $\bar{d}$ with $m a$ 'rîfa, could perform devotional service well to God.

Sheikh Yv̄suf, even clings to God's transcendence, but he still believes that God encompasses everything (al-ahāta) and exists everywhere (al-ma iyya) over His creation. ${ }^{13}$ However, he was very careful not to bind himself with the doctrine of pantheism by saying, even though God appears himself in His creation, it does not necessarily mean that His creation is God himself; all creation is only an allegorical or metaphorical being (al-mawjōd al-majāzi), not a real being (almawjōd al-haqiq $\bar{l}$ ). Thus, likes al- Sinkili, he believes that the creation is only a shadow of God. According to Sheikh Yṽsuf, the word God in His creation does not mean the presence of God Himself in their selves. ${ }^{14}$

In the concept (al-ahâta) and (al-ma iyya), the Lord descends (tanazzul), while the man or servant ascends (taraqqi), a spiritual process which brings them closer. It should be noted and remembered, according to Sheikh Yūsuf, the process will not take shape in the final unity between the servant and the Lord, while both are more closely linked together; in the end the servant remains the servant and God remains God (al-'abdu 'abdun wa al-Rab Rabbun). With this, Sheikh Yv̄suf appears to reject the subtle concept of Wahdat al-Wujv̄d (Unity of Being or Ontological Monism) Ibn 'Arabi and the concept of al-Hulv̄l (Divine

\footnotetext{
${ }^{10}$ Muzdalifah Sahib. Sheikh Yusufal-Maqassary, His Religious Mystic's Ideas in Indonesian and South African Scholars Works with Special Reference to Mațálib al-Sálikín Treatise. (A Research at Leiden University: unpublished, 2011) and Azyumardi Azra. The Transmission of Islamic Reformism to Indonesian: Networks of Middle Eastern Malay-Indonesian "Ulama" in the Seventeenth and Eighteenth. (A Dissertation, Columbia University: UMI, 1992).

${ }_{11}^{11}$ Al-Maqassary, Al-Nafhat al-Saylániyyah, Naskah Arab MSKBG 101, F Or A 13d (I), p. 2

${ }^{12}$ Al-Maqassary, Mațálib al-Sálikín. Naskah Arab MSKBG 108, F Or A 13b (3), p. 1-2.

${ }_{13}$ Al-Maqassary, Al-Nafhat al-Saylániyyah, p. 2-3; Mațálib al-Sálikín, p. 5; Sirr al-Asrăr. Naskah Arab MSKBG 101, F Or A 13d (8), p. 86/Or 7025 [3], p. 70-72; Zubdat al-Asrăr. Naskah Arab MSKBG 101, F Or A 13d (2) Id., p. 31; Daf'u l-Balá', in Tudjimah, Sheikh Yúsuf ..., p. 99.

${ }^{14}$ Al-Maqassary, Al-Nafhat al-Saylániyyah, p. 22; Zubdat al-Asrăr, p. 32
} 
Incarnation) Abū Manșv̄r al-Hallāj. In his opinion God cannot be compared with anything (laysa kamithlihi syay'). Instead he tends to take the concept of Wahdat al-Shuhv̄d (Unity Consciousness or Monism Phenomenologist) of al-Ghazali. ${ }^{15}$ Thus, while he carefully estranges himself from the controversial doctrine of Wahdat al-Wujv̄d (Unity of Being or Ontological Monism) Ibn 'Arabi and al-Hulv̄l (Divine Incarnation) Abū Manșv̄r al-Hallāj, Sheikh Yv̄suf took the doctrine of Wahdat al-Shuhv̄d of al-Ghazali which is developed by Ahmad al-Sinkili and Shah Walì Allāh, then later developed by him into the doctrine of' Wahdat alSamād '(Unity of dependence all) on the basis of the verse of al-Ikhlash (QS. 112: $1-4){ }^{16}$

A prominent feature of the theology of Sheikh Yṽsuf, the Oneness of God is that he tried to unify and reconcile all the attributes or the qualities of God, which according to the Islamic belief, God has attributes that seem contradict one another. God, for example, is believed to be the Beginning (al-Awwal) and the Last (al-Äkhir); the Outward (al-Zāhir) and the Inner or Inward (al-Bätin); the One who gives guide (Al-Hadi), but also the One who leaves human Lost (alMudill). According to him, all the attributes of God that seem to contradict each other should be understood according to the Oneness of God Himself. If you emphasize certain attributes and then ignore the others, this leads to the wrong belief and practices. The reality or nature of God is the unity of pairs of conflicting Attributes, and no one who knows His secret, except those who have been given knowledge by God Himself. ${ }^{17}$

Ma'riffah therefore, according to Sheikh Yv̄suf is that you know your beginning comes from Him and with Him you go back again, so you will return to Him that you come from. Like the ocean, if water levels come through the river, then the water will return to the sea, as its condition in the rivers. This means that water will never be changed essentially as water. ${ }^{18}$ In other words, ma 'rifah is the existence of God, Who brings together two contradictory things as mentioned above, or it can be said that he was the one God, if He is the Beginning be He the Last, then He will return as He Who early. So, He is the First, as He Who the Last and Early. That is, He will not be changed from His reality as the Essence of the One, Who has all those attributes. This case is never discussed in other scholars' works.

The theology of Sheikh Yv̄suf is the same as Ash'ariyah theology; even he was very obedient to the doctrine of Ash 'ariyya. He emphasized the full fidelity on the six pillars of faith: faith in Allāh, His angels, His Books, His Prophets, the day of resurrection and the God's qad, an and qadar. Furthermore, in conjunction with perfect faith in all these pillars of faith, he urged fellow Muslims to fully accept the ambiguous meaning of some verses of the Koran or al-'Ayät alMutashäbihāt. ${ }^{, 19}$ Searching or questioning the real meaning of such verses is a

\footnotetext{
${ }^{15}$ Al-Maqassary, Al-Nafhat al-Saylániyyah, p. 38-39

${ }^{16}$ See Sahib Sultan, Allah and the Way ..., p. 169-174

${ }^{17}$ Al-Maqassary, Taj al-Asrăr. Naskah Arab MSKBG 101, p. 76-77; Kaifiyat al-Mungh̄̄ dalam

Tudjimah, Sheikh Yusuf ..., p. 43-44; bandingkan dengan Hamid, Sheikh Yúsuf ..., p. 197-198.

${ }^{18}$ Al-Maqassary, Mațálib al-Sálikín, p. 7

${ }^{19}$ Al-Maqassary, Al-Nafhat al-Saylániyyah, p. 2
} 
sign that one does not fully trust in God, only by accepting the verses as such, a wanderer or traveler in the path of God will be able to achieve God's grace or bless. $^{20}$

In addition, Sheikh Yv̄suf emphasized the destiny of man based on the Will of God as well as theological views of Ash'ariyyah. For example, he repeatedly asked the Muslims to sincerely receive their fate or divine providence and divine decree (al-qad̄a wa al-qadar), whether good or bad. ${ }^{21}$ But he stressed, humans cannot just surrender to them. More importantly, people should not blame God for their bad deeds, because they should not just accept it as their fate. Instead, they must try to break away from sinful behavior and improve their humanity by thinking about the creation of God and do good deeds. By this way, Sheikh Yv̄suf believes, people will be able to create a better life in this world and the hereafter.

Therefore, Sheikh Yv̄suf also called on the faithful who are on the way to Allāh never to despair at the mercy of Allāh, for verily Allāh's mercy exceeds His anger, but he also emphasized that we are always afraid of him. Sheikh Yūsuf said: Antu nikanaya tappa anrong gurunnai pangngassenganga, naiya pangngassenganga empoannai mallaka siagang manrannuanga, ${ }^{22}$ this means: Faith is the great teacher of science (the Islamic science), the Islamic science as a basis for fear and hope.

Indeed, fear that comes with expecting God's love is only a pious attitude of the believers (of Islamic knowledge), in accordance with the words of God as in the following

“...Fear Me, if you are (true) believer.",23

"...It is only those who have knowledge among His slaves that fear Allāh."24

In al-Nafahāt al-Saylāniyya, he told his students: it is incumbent for you to stand between khauf or fear and raja $\bar{a}^{\prime}$ or hope, meaning that you have to unite both of them by characterizing both. Both are required, although each within the limits of its essence. Because fear is quiet of hope, and hope is quiet from fear. Prefer one is not blessed in this matter for a Gnostic man and a perfect haqiqqa expert. Truly preferring something in this case is something that will not come to its limit and will not reach the perfect place. It would just be useful if humans could characterize both. ${ }^{25}$

Unlike other șüfis, who thought that the highest maqām is mahabba or love, and some others considered the highest level is $f a n \bar{a}^{\prime}$ and $b a q \bar{a}^{\prime}$, but Sheikh Yṽsuf virtually the only one who saw al-mutlaqat al'ubudiyya (unrestricted adoration), as the highest maq $\bar{a} \mathrm{~m}$ or the highest stage in sulûk on the path of Allāh. By taking the verse of al-Qur'an Surat al-Isrā, whereby when the Prophet Muhammad created walking or journeying one night from al-Masjid al-Harām to al-Masjid al-Aqsā until he reached the seventh sky even to meet with God in

\footnotetext{
${ }^{20}$ Al-Maqassary, Qurrat Al-'Ayn. Naskah Arab MSKBG 101, p. 54-55

21 Al-Maqassary, Al-Fawáih al-Yúsufiyya. Naskah Arab MSKBG 108, p. 80-1; Tuhfat al-Abrár. Naskah Arab MSKBG 101, p. 78-79; Al-Nafahát al-Saylániyya, loc.cit, p. 8-9

${ }^{22}$ Nuruddin, Daeng Magassing. Riwayatna Tuanta ..., p. 106

23 QS. Ali-Imran [3]: 175

${ }^{24}$ QS. al-Fâthir [35]: 28

${ }^{25}$ See Al-Naf̣at al-Saylániyyah dalam Tudjimah, Sheikh Yusuf ..., p. 43; bandingkan dengan Sahib Sultan, Allah and..., p. 282
} 
Sidrat al-Muntahā, he was not called by the title of Prophet or my love, but he only called as My servant, since nothing glorifies more the level of the servant except the level of God especially the Creator, Allāh. ${ }^{26}$ Thus, how glorify the name of a servant is, its place is before God and therefore not all of his creation can be called directly as His servant, except those close to Him; and when Muhammad meet with God directly in Sidrat al-Muntahā, he never says the words shațahāt as what had been said by Abū Mansur al-Hallāj and Ibn 'Arabi unless he only said 'I testify that there is no God but Allāh.' Muhammad is a leader and guide, a chosen people and the most perfect human in this earth, however he never said 'Anä al-Haq' or I'm God, unless he simply said "I am only human like all of you" 27 The man who has successfully reached the stage means he has reached the center of his being, and therefore he is called the perfect human (al-Insān al-Kämil). ${ }^{28}$ According to Sheikh Yūsuf, by achieving this stage of the perfect human, a servant stripes his allegorical being (al-maujōd al-majāzi) and gets into his real nothingness. His nothingness is taken by God as a mirror (mir'a) from Himself. God further reveals Himself (tajalli) to that servant. In other words, the servant who has been so absorbed $\left(\right.$ fan $\left.\bar{a}^{\prime}\right)$ into the existence of God will be able to identify or recognize the secrets of his Lord. Furthermore, he sees through His sight, hears with His Hearing, reaches with His hand, walks with His legs, talks with His Word and thinks with His mind. ${ }^{29}$

Sheikh Yṽsuf tried hard not to catch up in the long and heated controversy regarding the concept of Unity of Being between the servant and the Lord by saying that although the servant is able to enter the existence of God, however he remains human, while God remains God. ${ }^{30}$

Like most other șvfīs, Sheikh Y v̄suf obviously is a șvifi who clings to the positive view of mankind as a whole. In his opinion, every person has the innate tendency to believe in God, and those closest to him are the ones who can maintain the tendency in the right way. ${ }^{31}$ Therefore, he urged the faithful not to criticize or look down on those who do not believe in God and the people who live a sinful life, the believers must have a good suspicion (husnu al-zann) of all people including people who are not believers. Citing Ab̄u Madyan al-Tilimsānī, he reminds them that the flaws of unbelievers may be better than the pitfalls of the faithful. ${ }^{32}$ With such a view is not surprising that none of the works of Sheikh Yv̄suf-deprecating the Dutch, who bring a lot of misery upon his life, and because he accepts the fate that has been destined to him by God, then he enjoyed his life until his death in South Africa's Cape of Hope, far from his homeland. May God always shine on his tomb and his descendants' grandchildren, amen.

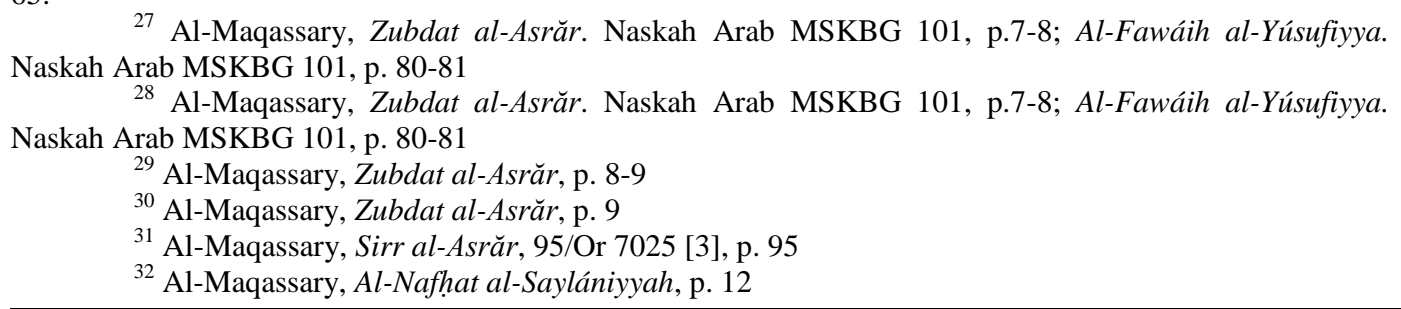


In accordance with the level of their trust in God, Sheikh Yv̄suf classifies the faithful into the four categories. The first, the people who just say the statement of faith (shahāda) without true faith, are called hypocrites (al-munāfiq). The second category is those who not only say the shahadah, but also plant it into their souls; this group is called the common faithful (al-mu'min al-awwām). The third category is the class of believers who truly realize the inward and the outward implications of the statement of faith in their lives: they are called special or elite groups (ahl al-khawās). The final class is the highest category of the faithful, who rise above the third class by intensifying their shahädah, especially by practicing tasawwuf in order to get closer to God. They are accordingly called the select of the elite or very special groups (Khāss al-Khawās). ${ }^{33}$

Tașawwuf of Sheikh Yūsuf is classified as a neo-șufist. ${ }^{34} \mathrm{He}$ calls tasawwuf with the name al-Tariqat al-Muhammadiyyah (the Way of Muhammad or Mohammadan path) which constitutes the right path "al-Sirāt al-Mustaqīm."35 Throughout his writing he makes it clear that the mystical way can only be trod through a total commitment both outwardly and inwardly to the legal doctrine of Islam. He maintains that committing oneself simply to the shari' ah is better than practicing tașawwuf while ignoring Islamic legal precepts. ${ }^{36}$ He even goes so far as to classify as zindiq (freethinkers) and mulhid (heretics) those who believe that they will be able to get closer to God without practicing such rituals as prayer and fasting. ${ }^{37}$

Sheikh Y $\bar{v}$ suf is very enthusiastic in his efforts to reconcile the divine law aspects (shari' 'ah) and divine reality (haqĩah) of Islam. In this regard, he repeatedly narrates statements of unnamed authorities who assert that those who keep only the sharì'ah without the haqìqa are fäsiq (sinful men), and those who practice tașawwuf while ignoring shari 'ah are zindiq. ${ }^{38} \mathrm{He}$ also quoted the words of Gnostic men (al- 'Arif bi Allāh) that: "All sharī'ah (divine law) without haqīqah (divine reality) is vanity and all haqiqqah (divine reality) without sharī'ah (divine law) is 'atil (imperfect). Then he stated that the best thing to do is to harmonize both; as in his statement, "Let it be known, my follows, divine law or exoteric devotion without divine or esoteric reality is like a body without a soul or a spirit $(r \bar{v} h)$, whereas divine reality or esoteric occupation without divine law or exoteric devotion is like a spirit without a body." ${ }^{39}$ Finally, he cites the hadith of the Prophet who said the Prophet was sent by God in order to bring sharì'ah and haqīqah as well. ${ }^{40}$ Thus, Sheikh Yv̄suf insisted that everyone who wants to take the path of God or enter the tariqah has to practice previously all the teachings of the shari 'ah. ${ }^{41}$

\footnotetext{
${ }^{33}$ Al-Maqassary, Al-Barkat al-Saylániyyah. Naskah Arab MSKBG 108, p. 71. Bandingkan AlNafhat al-Saylániyyah, p. 4-5

${ }^{34}$ See Azra, Azyumardi, Jaringan Ulama ...., p. 294

${ }_{35}$ Al-Maqassary, Al-Fawáih al-Yúsufiyya, p. 83; Qurrat al- 'Ayn, p. 52; Sirr-al-Asrăr, p. 94/Or 7025

[3]: 89

${ }^{36}$ Al-Maqassary, Zubdat al-Asrăr, p.37

${ }^{37}$ Al-Maqassary, Zubdat al-Asrăr, p. 42

${ }^{38}$ Al-Maqassary, Al-Fawáih al-Yúsufiyya, p. 82, Al-Nafhat al-Saylániyyah, p. 4, Tajal-Asrăr, p. 7374, Zubdat al-Asrăr, dalam Lubis p. 32

${ }^{39}$ See, al-Maqassary, Al-Nafhat al-Saylániyyah, p. 4; Taj al-Asrăr, p. 74

${ }^{40}$ Al-Maqassary, Sirr al-Asrăr, p. 94/Or 7025 [3], p. 89

${ }^{41}$ Al-Maqassary, Matálib al-Sálikín, p. 9.
} 
Furthermore, Sheikh Yv̄suf argued for a list of ways to approach God. First by means akhyār (best people), that is by performing a lot of worship of prayers, fasting, reading the Qur'an and the hadith of the Prophet-may Allāh bless and grant him peace, struggled in the way of Allāh (al-jihād fì sabil Alläh), and other exoteric devotion. The second way is the way of the people mujāhidāt alshaq $\bar{a}^{\prime}$ (those who struggle against adversity or hardship) by way of rigorous training to break away from bad habits and purify the mind and soul. The last is the way of people of dhikr (ahl al-dhikr), that is, people who love God, both outwardly and inwardly; they take very special care of the two kinds of devotion. ${ }^{42}$

However, Sheikh Yv̄suf prevents the traveler on God's path (sālik) from treading his own way in searching for the truth; this would only be misleading because the devil or Satan will be his master or teacher. Therefore, he should look for a trusted and experienced șvfi sheikh or șvifi master, even if he, as a consequence, must travel to distant places, leaving family and homeland. But there is no other way; only with the guidance of a trusted șvf $\bar{\imath}$ master (sheikh) will he be able to get closer to God; because the master or sheikh will show him the right and the surest way to achieve spiritual progress. ${ }^{43}$ Moreover, the $s \bar{v} f \bar{\imath}$ sheikh is a successor of the Prophet: he is his representative, both outwardly and inwardly. ${ }^{44}$

Sheikh Yv̄suf differentiates himself from most other prominent scholars by having a high position as well as awards granted to him. Unlike Ahmad AlQushashi who encourages a sālik to leave his master if the master disobeys shari' 'ah, Sheikh Yv̄suf adheres to earlier notion of the position of the șvjfi of his students or disciples. Thus, for Sheikh Yv̄suf, once a sālik pledges his allegiance (bay'a) to a certain $\bar{a}$ master, he must totally obey him even if the Sheikh does something which does not necessarily lead to a closer communion with God or does something contrary to the teachings of the $\operatorname{shari}^{-} a h$. The reason is that the sheikh is not infallible and evens some of the Prophets made mistakes. ${ }^{45}$ However if the sheikh makes mistakes by transgressing rules of the sharī'ah, Sheikh Yṽsuf reminds the student to keep up his good deeds and not follow his master's transgression. ${ }^{46}$

Sheikh Yv̄suf also discussed at length several special worship and steps toward spiritual progress which should be undertaken by the travelers in God's fate. He put special emphasis on the $d h i k r$. His $d h i k r$ was primarily the vocal $d h i k r$ (jahr) such as Lā ilāha illā Allāh, Allāh-Allāh and Huwa-Huwa, as taught by both 'Ibrahim al-Kurān̄i and Muhammad ibn 'Abd al-Bāqī al-Naqshabandī. ${ }^{47}$ In

\footnotetext{
${ }^{42}$ Al-Maqassary, Al-Nafhat al-Saylániyyah, p. 23-24

${ }^{43}$ Al-Maqassary, Al-Nafhat al-Saylániyyah, p. 2

${ }_{45}^{44}$ Al-Maqassary, Al-Nafhat al-Saylániyyah, p. 24-25

${ }_{45}$ Al-Maqassary, Al-Nafhat al-Saylániyyah, p. 24-25, compare with Zubdat al-Asrăr, p. 12-13 in Lubis, Nabilah, Sheikh Yúsuf ..., p. 105-107

${ }^{46}$ See, al-Maqassary, Habl al-Warìd Li Sa 'ădat al-Murid in Tudjimah, Syekh Yusuf ..., p. 114

${ }^{47}$ For a more detailed explanation of worship relating to dhikr, see al-Maqassary, Fath Kaifiyyat alDhikr. Naskah Arab MSKBG 101, p. 78-80Compare al-Maqassary, in Qurrat al-Ayn, p.2 with Sahib Sultan. Syekh Yusuf Tuanta Salamaka, Ulama Sufi, Pejuang Abad ke 17 dan Pahlawan Nasional Dua Negara. Ed. Muhammad Amin Sahib, (Makassar, YAPMA: 2006), h. 82
} 
accordance with the concept of purification of faith, according to Sheikh Y v̄suf, the essence of dhikr is full recognition to the Oneness of God. At the preparatory level (al-mubtadī) for awwām people, people who do dhikr in his faith affirms that no one should be worshipped but Allāh as the meaning of dhikr للا اله الا also called dhikr of the tongue. At the next level (al-mutawassith) among ahl alkhawās (special people), he recognizes that he seeks and loves nothing but Allāh, and that is what intentended by dhikr - or also called liver or heart dhikr. At the last level (al-muntahī) for the ahl al-Nihaya among ahl akhās al-khawās (very special people), he fully believes that no other beings except God are what is intended by the dhikr هو - or secret dhikr.

\section{B. Sheikh Yōsuf's Reform Ideas in the Spread of Islam in Gowa-Makassar}

In the early of the seventeenth century, Gowa and Tallo Kingdom had become an Islamic Kingdom, and of course the Muslim population had been increased day by day, but they still had bad habits, customs and traditions such as they still liked to give services to some idol places, did gambling, drank 'tuak'/ wine/alcoholic drinking and did cock fighting. Those became their habits although they had converted into Islam.

Here, the role of Muhammad Y $\bar{v}$ suf as a candidate $\bar{a}$ from Gowa-Makassar to give spiritual enlightenment begins from the King of Gowa himself and then spreads to his society. Then after he became a great $\bar{a}$, he then tried to make a reform by instilling his teaching through some of his disciples to purify the believes or aqidah of Muslim in Gowa-Makassar, South Sulawesi. In this case, he tried to purify the Islamic pratice in the middle of his community by trying to reconcile shari' 'ah and haqiqqah. ${ }^{48}$

As far as I am concerned that in the seventeenth century, some Muslims in Gowa-Makassar still worshipped or provided services toward idol places such as anjak, saukang, pantasak and sallerang. ${ }^{49}$ Whatever the names of the places were, those remained idol places which are forbidden to be worshipped or given services when one had converted to Islam. In addition to it, the society of GowaMakassar still liked to drink alcoholic beverages or tuak, and did gambling and cockfighting in the crowded place especially among the Bajeng people. Nevertheless, those the act sins can be a big danger to his birth land; according to him that the collapse of an empire due to the weakness of the faith of the people, and so did the Islamic law or shari' ah become weak by the weakening of the empire and the destruction of the rule of power. The robust of an empire ensure the enforcement of shari 'ah and the rules of Islam. Therefore, the ruler who

\footnotetext{
${ }^{48}$ Compare with Muzdalifah Sahib, Sheikh Yusuf al-Maqassary, His Religious...., p. 25

${ }^{49}$ Anjak (small beds which are put in the upstairs of the house that are considered as the resting place of their ancestor's soul, who can help or disturb if he was not worshipped or given ritual offerings.). Saukang (the houses which are built in the middle of the jungle or at the edge of the village, near to the big trees, as a place for giving ritual offerings to their ancestor). Pantasak and sallerang (both of them are the same place of sacrifices with anjak. They are only different in forms, Pantasak forms as small houses and sallerang forms as a quadrangle net that was made of yellow bamboo). (Lihat, Sahib Sultan Penilaian dan Penghargaan Masyarakat Gowa terhadap Sheikh Yūsuf. Sebuah Skripsi, (Ujungpandang, IAIN Alauddīn: 1982).
} 
enforces religious doctrine can ensure the implementation of $\operatorname{shari~}^{\prime} a h^{50}$

No matter how delicious alcoholic beverages maybe to drink, it is nevertheless forbidden because the effect is very bad for humans. Especially when someone is in a drunken state, he can do the worst things in his life, which will bring remorse. Although the drink is said to be able to strengthen an army for battle, in the end the drink itself that would defeat the army and cause him to collapse. In other words its harm is much greater than its benefit.

As for gambling and cockfighting, both are forbidden for a Muslim, because in the end, both will bring harm. Loss of time and loss of materials can even bring disaster such as the great fights and quarrels, ultimately debts happened and piled up between the two parties, both winners and losers, because the actual benefit is for the bookie of gambling or cockfighting himself and not for the participants of gambling/cockfighting. Each time the participant of gambling / cockfighting win, he still want to try it over and over until he lose everything, even losing his own life without realizing it.

Seeing everything that was bad rampant among Muslims in Gowa, Muhammad Yōsuf as a candidate șv́fi at the time then felt sad and very disappointed when the King of Gowa did not crack down on his people, including the royal family of Gowa, until the sparked of words out of the mouth of Muhammad Yṽsuf that "Gowa will be destroyed like the destruction of lime in a betel pot," which ultimately makes the King afraid off and conscious his mistakes but he still not had brevity to do something for changing the condition of his people. Then he left Gowa in 1644 for wandering in search Islamic knowledge began from Banten, Aceh, India till to the Middle East and returned to his country in the early of 1668 with his students 'Abd al-Bașīr al- Darīr. ${ }^{51}$

When Shaykh Yvisuf returned to his country, he still heard about the bad rampant in the middle of Muslims communities in Gowa-Macassar, and then he gave his disciples a mandate to assist the King of Gowa in combating the acts of sins and especially to his student 'Abd al-Bașī al-Ḍarìr to spread his Khalwatiyyah or Yṽsufiyyah tarīqah in South Sulawesi.

Therefore, at the time in the seventeenth century, on the name of Shaykh Yv̄suf, his students I Kare Nyampa and I Daeng Mallolongang had succeeded in conducting a mop-up operation to all places of idols, wine (alcoholic) drinking, except sweet wine or 'tuak manis' (sweet wine or non-alcoholic beverages), gambling or cockfighting over permits of the King of Gowa. Because the King aware of what Shaykh Yṽsuf said several years ago for what will be happened on his kingdom, if all of them cannot be released.

Sheikh Yv̄suf as a great șvfi who has a great charisma, for simply his preaching from far, can influence the King of Gowa to do something that is good for his people, and by his charismatic preaching he can cause Muslims in Gowa to be better at the time, where he had changed the habits and cultural roots of Gowa society to be better than ever before.

\footnotetext{
${ }^{50}$ Compare with al-Maqassary, in Qurrat al- 'Ayn, p. 2 and Sahib Sultan, Sheikh Yüsuf Tuanta Salāmaka the Süfì Islamic Scholar, the Warrior of the Seventeenth Century and the National Hero of Two Countries. Translated and Edited by Muzdalifah Sahib (Makassar, YAPMA: 2006), p. 82

${ }^{51}$ Compare with Muzdalifah Sahib, Shaykh Yúsuf al-Maqassari His life Story.....p. 50-51
} 
Furthermore, his spiritual enlightenment completed by the spreading of his Tarīqah Khalwatiyyah (Khalwatiyyah Sūfi Path) in South Sulawesi by his șvfi student 'Abd al-Bașir al-Raffānī, a blind șv̄fì but his șv̄fi knowledge was very high and then developed by one of his offspring Muhammad Sultān Baitullāh with Yōsufiyyah Ș̂́fī Path in Macassar and surrounding areas (died 1648). ${ }^{52}$

Even though Sheikh Yv̄suf 's treatises may be limited to mysticism, this does not hide his main concern, namely the renewal of confidence and practice of Islam in the archipelago and in South Africa through the teaching of $\bar{a}$ sm which is more oriented to the shari'ah (divine law) which he tried hard to reconcile between sharī'ah (divine law) and haqiqqah (divine reality). He quoted the words of Gnostic men (al-'Arif billah) that: "All sharī'ah (divine law) without haqīqah (divine reality) is vanity, and all haqigah (divine reality) without shari' 'ah (divine law) is 'atil (imperfect). He also states the words of the Messenger of Alläh that: "Whoever doing fiqh (sharī'ah) but has no mysticism, he is fasiq (a sinful man); and whoever has mysticism but no fiqh (sharì'ah), he is zindiq. Who collect both (fiqh and mysticism), so he gets haqiqah . ${ }^{53}$ The words of Prophet: "Truly, I am delegated with shari'ah (divine law) and haqiqah (divine reality, while all Prophets are only delegated with shari' 'ah (divine law). ${ }^{54}$ and others.

Therefore, his main priority in reforming his mystic teaching for the Muslim believers especially in Gowa-Macassar, South Sulawesi, Indonesia is by way of implementing a teaching of $\bar{a}$ sm which is more oriented to the shari 'ah , where he tried hard to reconcile shari' $a h$ and haqiqqah. Among the various kinds of thariqahs affiliated with him, Tariqat al-Khalwatiyyah is the famous one, later popular with Khalwatiyyah Yvisufiyyah which finds fertile land especially in South Sulawesi which was spread out by one of his students, Abd. Bashir al- Raffāni and then by one of his offspring Sheikh Muhammad Sulțān Baitullah (died 1948) and then by his son Sahib Sultān until now. So, if the people of South Sulawesi, and also of Banten West Java, have been known generally the fervent Muslims in the archipelago, one can hardly underestimate the role of Sheikh Y $\overline{s u f}$ in developing that identity. He must even be given an appreciation as high as possible.

\section{CONCLUSION}

Based on the discussion above, some conclusions can be made as follows:

Sheikh Yṽsuf was not only a brave man in fighting against the colonizer as a defender of human rights, but also in wandering to seek and deepen his Islamic knowledge from Aceh, India to the middle East and then became a great $\bar{a}$ who taught Islamic mysticism starting from Mecca in 1662 till the rest of his life in Cape town 1699, and he is considered even as a National Hero of two countries, Indonesia and South Africa and as a reformer in the Islamic mystic world or a neo șifism.

The main concept of religious and mystic Sheikh Yv̄suf is the purification of

\footnotetext{
${ }^{52}$ Mulyati Sri, Hj.MA. Dr. Mengenal dan Memahami Tarekat-Tarekat Muktabarah di Indonesia. (Jakarta, Prenada Media: 2004), p. 128.

${ }^{53}$ Nabilah Lubis, Syekh Yusuf al-Taj ....., p. 32

${ }^{54}$ Nabilah Lubis, Syekh Yusuf al-Taj ......, p. 93
} 
belief ('aqidah) in the Oneness of Allāh or in the Unity of God (tawhīd). This is his attempt to explain God's transcendence (Ilāh) over His creation. Citing alIkhlash verse (QS. 112:1-4) and another verse of Al-Qur'an in al-Shura' verse which states that nothing is comparable unto Him (QS. 42: 11), Sheikh Yv̄suf emphasized that the Oneness of Allāh is unlimited and absolute. Tawhīd is the essential component in Islam; a man who does not have tawhìd is an infidel. More deeply, he illustrates pure tawhìd or the immaculate tawhīd as a tree with its branch and its leaves; ma 'riffah knowledge is like its branch and its leaves; while prayer is like its fruit. Furthermore he said that if you got the tree, you will get its branches and leaves, and if you got them, even you look for fruit of the tree. If you do not get its branches and leaves, it is impossible to get its fruit. This is a 'majazi' or a metaphor sample that we said, in order that you can understand real nature (actually). A man who does not know ma 'rîfah knowledge is stupid (jähil) and a man who does not practice ibādah or prayer is a sinful man (fäsiq). Therefore, tawhìd without ma 'rïfah is like a tree without branches and leaves, and it is impossible to get its fruit, except if the branches and leaves of the tree grew up again, then its fruit can be hoped. In other words, only a man, who has tawhìd with ma'riffah, could perform devotional service well to God. This teaching was used as the basic reform ideas in the spread of Islam in Gowa-Macassar, South Sulawesi and then brought a big changing to the cultural of his society and then made Muslim in Gowa-Makassar to be a more fervent Muslim.

Therefore, one of the reform movements in his homeland was that he tried to pull out and then to release the people of Gowa-Makassar from the bad habits such as activities in serving idols / idols places, alcoholic beverages, cockfighting and gambling in crowded places. Because those can be a great danger to his native land; he said that the collapse of an empire because of the weakness of the faith of its people. On the other hand, the strength of an empire can ensure the enforcement of shari 'ah. But it also depends on the leader. A good leader / ruler is one who able to enforce the Islamic law or shari' $a$ h in the middle of his society. Thus the main priority in the renewal of his mystical teachings for Muslims believers especially in Gowa Makassar, South Sulawesi, Indonesia is the purification of confidence by implementing șifism which is more oriented to the sharī'ah; where he tried hard to reconcile shari' 'ah and haqiqah. Among the various types of Șivfi Paths affiliated with him, Tariqah Khalwatiyyah as the famous one, which is later more popular with Khalwatiyyah Yvisufiyyah that has found fertile land especially in South Sulawesi. Thus, his role in the spread of Islam in Gowa-Makassar that must obtain an appreciation as high as possible. May Allāh always illuminate his tomb until the end period, amen.

\section{REFERENCES}

Al-Hilali Taqiuddin Muhammad, Dr and Dr. Muhammad Muhsin Khan. Interpretation of the Meanings of the Noble Qur'an in the English Language. Riyadh-Saudi Arabia, Dar-us-Salam Publications, 1995. 
Azra Azyumardi. The Transmission of Islamic Reformism to Indonesian:

Networks of Middle Eastern Malay-Indonesian "Ulama" in the Seventeenth and Eighteenth. A Dissertation, Columbia University: UMI, 1992.

Azra Azyumardi. Jaringan Ulama Timur Tengah dan Kepulauan Nusantara Abad XVII \& XVIII. Akar Pembaruan Islam di Indonesia. Edisi Refisi, Jakarta: Kencana. 2007

Azra Azyumardi. Shaykh Yṽsuf: His Role in Indonesia and South Africa. A paper presented for "One-day Seminar on Slavery and Political Exile." Cape Town, South Africa: Slave Lodge, the Iziko Museums, March $23^{\text {rd }} 2005$.

Cence, A.A. "Pemujaan Syeikh Yv̄suf di Sulawesi Selatan". Sejarah Lokal di Indonesia. Editor: Taufiq Abdullah. Yogyakarta: UGM, 1979

Hamka. "Perjuangan Syeikh Yusuf Taj al-Khalwati", Almanak Muhammadiyah. XX, 1959/1960.

Ligtvoet. 1877. Transcriptie Van De Lontara Bilang of Het Dagboek der Vorsten Van Gowa en Tallo. S. Graven Hage: Volksdrukkerij, 1877.

Lubis, Nabilah. Syekh Yusuf al-Taj al-Makasari. Menyingkap Intisari Segala Rahasia. Bekerja sama dengan Fakultas Sastra Universitas Indonesia \& Ecole Francaise d'Extrême-Orient, Bandung: Mizan, 1996.

Mulyati Sri, Hj.MA. Dr. Mengenal dan Memahami Tarekat-Tarekat Muktabarah di Indonesia. Jakarta: Prenada Media, 2004.

Daeng Magassing, Nuruddin. Riwayatna Tuanta Salamaka Sehe Yusufu. Makassar: Volksdrukkerij, 1933.

al-Maqassary, Syeikh Ȳ̄suf. Al-Nafahāt al-Saylāniyya. Naskah Arab MSKBG 101, F Or. A 13d (1).

al-Maqassary, Syeikh Yv̄suf. Zubdat al-Asrār. Naskah Arab MSKBG 101, F Or. A 13d (2) Id.

al-Maqassary, Syeikh Yūsuf. Taj al-Asrār. Naskah Arab MSKBG 101, F Or. A $13 \mathrm{~d}(5)$

al-Maqassary, Syeikh Yv̄suf. Sirr al-Asrār. Naskah Arab MSKBG 101, F Or. A $13 \mathrm{~d}(8)$

al-Maqassary, Syeikh Yv̄suf. Tuhfat al-Abrār. Naskah Arab MSKBG 101, F Or. A $13 \mathrm{~d}(9)$

al-Maqassary, Syeikh Yv̄suf. Qurrat al'Ayn. Naskah Arab MSKBG 101, F Or. A $13 \mathrm{~d}(13)$

al-Maqassary, Syeikh Yv̄suf. Mațālib al-Sālikīn. Naskah Arab MSKBG 108, F Or A $13 b(3)$

al-Maqassary, Syeikh Ȳ̄suf. Al-Fawāih al-Yv̄sufiyya. Micro film copy from MSKBG 108, Arabic of UB Leiden, F Or A 13 b (6)

Sahib, Muzdalifah. Sheikh Yusuf al-Maqassary, His Religious Mystic's Ideas in Indonesian and South African Scholars Works with Special Reference to Mathalib al-Sälikīn Treatise, A Research at Leiden University, unpublished, 2011.

Sahib, Muzdalifah. Sheikh Yusuf al-Maqassary dan Pembaruannya dalam Asme. Makassar: Yayasan al-Mahasin, 2016.

Sahib, Muzdalifah. Muzdalifah Sahib, Shaykh Yōsuf al-Maqassarī His life Story as a National Hero from Gowa, South Sulawesi to Cape Town, South 
Africa and a Reformer in the Islamic Mystic World. Revised Edition, Makassar: Alauddin University Press, 2014.

Sultan Sahib, Penilaian dan Penghargaan Masyarakat Gowa terhadap Sheikh Yūsuf. Sebuah Skripsi, Ujungpandang, IAIN Alauddīn, 1982

Sultan Sahib, Syeikh Yusuf Tuanta Salamaka the Sufi Islamic Scholar, the Warrior of the Seventeenth Century and the National Hero of Two Countries. Translated and Edited by Muzdalifah Sahib, Makassar: YAPMA, 2006.

Sultan Sahib, Allāh dan Jalan Mendekatkan Diri Kepada-Nya dalam Konsepsi Syeikh Yusuf. Edited by Dra.Hj. Muzdalifah Sahib, M.Hum, Makassar: Yapma, 2008.

Tudjimah, Syeikh Yusuf Makassar Riwayat dan Ajarannya. Jakarta: Universitas Indonesia (UI Press), 1997. 